\title{
Knowledge, perception and preventive practices of COVID-19 among Primary Health Care workers in Ogun State, Nigeria

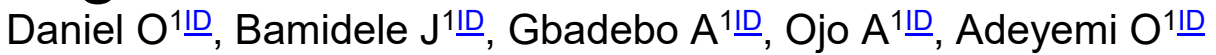

${ }^{1}$ Department of Community Medicine and Primary Care, Olabisi Onabanjo University Teaching Hospital, Sagamu, Ogun State, Nigeria.

Submitted: $21^{\text {st }}$ September 2021

Accepted: $10^{\text {th }}$ December 2021

Published: 30 th December 2021

ID: Orcid ID

\begin{abstract}
Objective: This study was carried out to determine the COVID-19 knowledge, perception, and preventive practices among primary health care workers in Ogun state.

Methods: A descriptive cross-sectional study was carried out among 339 primary health care workers in Ogun state using self-administered questionnaires. Knowledge of COVID-19 was graded as good with a minimum score of $75 \%$ while perception was graded as good with a score greater than the mean scores. Preventive practices were categorized as good with minimum scores of $75 \%$. Associations between knowledge, practice, and categorical variables were assessed using the chi-square test with the level of significance set at $p<0.05$

Results: The mean age of respondents was $42.30 \pm 8.73$ years. The major source of information on COVID-19 was health training $(99.7 \%)$. A total of $50.7 \%$ had good knowledge of COVID-19 while $42.8 \%$ had a good perception of COVID-19. The majority $(92.9 \%)$ had good COVID-19 preventive practices. Length of years in service was significantly associated $(p=0.024)$ with knowledge of COVID-19.

Conclusion: About half of the health care workers had good knowledge of COVID-19 while the perception of COVID-19 was poor. However, preventive practices carried out among the healthcare workers were good. Efforts should be made to further improve the knowledge and perception of primary health care workers as they play a vital role in the delivery of health care services in the state.
\end{abstract}

Keywords: COVID-19, knowledge, perception, preventive practices, health care workers

\section{Plain English summary}

COVID-19 came into the global picture in January 2020 and health care workers needed to respond immediately to contain the spread of the disease. Therefore, there is a need to assess the COVID-19 knowledge, perception, and preventive practices among healthcare workers to ensure that they do not aid the spread of the disease by their lack of knowledge which could make them prone to misinforming the public. This study set out to assess the knowledge, perception, and preventive practices of COVID19 among primary health care workers in Ogun state. It was a study done at a specific point in time among 339 primary health care workers. From the study, the average age of the respondents was 42.30 \pm 8.73 years. The major source of information on COVID-19 for respondents was health training. A total of $50.7 \%$ had good knowledge of COVID-19 while $42.8 \%$ had a good perception of COVID-19. The majority $(92.9 \%)$ had good COVID-19 preventive practices. In conclusion, about half of the health care workers had good knowledge of COVID-19 while the perception of COVID-19 was poor. However, a preventive practice carried out among the healthcare workers was good. Efforts should be made to further improve the knowledge and perception of primary health care workers as they play a vital role in the delivery of health care services in the state. 


\section{Background}

Severe Acute Respiratory Disease Syndrome Coronavirus-2 (SARS-CoV-2) is a new form of coronavirus which was first reported in December 2019 following the occurrence of several cases of atypical pneumonia in the city of Wuhan in China. The virus has been confirmed to cause a form of illness known as COVID-19 (1). The World Health Organization declared the disease a public health emergency on January 30, 2020, and a pandemic by March 11,2020 (2).

As of $28^{\text {th }}$ June 2021, there were $180,654,652$ confirmed cases globally and $3,920,463$ deaths with the Americas being the most affected having slightly less than $50 \%$ of all the confirmed cases and the Western Pacific is the least affected with $<2 \%$ of confirmed cases. Africa is the second least affected with less than 4 million confirmed cases of the disease (3). As at that time, Nigeria had 167,467 confirmed cases and 2,119 deaths with the highest number of cases in Lagos state. Ogun state which is near Lagos had 4,684 cases and 51 deaths recorded (4).

The transmission of the disease was initially thought to be from animals to humans and thereafter human-to-human transmission has been reported. The latter occurs through direct, indirect, or close contact with people through infected secretions or respiratory droplets (5, 6). Airborne transmission can occur during medical procedures that generate aerosols even though it is not yet clear if it occurs in the absence of such procedures $(5,6)$. Transmission may also occur indirectly through touching surfaces that are contaminated with the virus in the immediate environment of an infected person. Although the virus has been detected in other biological samples such as urine and feces of some patients, there has been no published report of its transmission via feces or urine $(5,6)$.

COVID-19 usually presents with symptoms such as fever, fatigue, dry cough, malaise, and difficulty in breathing (7). Regular hand washing, social distancing, and respiratory hygiene such as covering the mouth and nose when coughing and sneezing are some of the primary preventive measures against the disease $(8,9)$.

Health care workers are very important stakeholders in the prevention and control of diseases within the healthcare settings and as agents of change within the community in which they live. They are likely to perform these roles effectively when they are armed with sufficient knowledge about the disease and how to prevent the spread of the disease both in the health care setting and in the community. Some studies have shown that health care workers have poor knowledge of the transmission of COVID-19. This is compounded with the recent infodemic around the COVID-19 epidemic (10, 11).

Primary Health Care $(\mathrm{PHC})$ is the entry point to the nation's health care system and as such health care workers at this level come in contact with suspected or asymptomatic cases of COVID-19 in the course of their daily work activities which puts them at a high risk of exposure to the virus. Currently, there is no widely accepted treatment for the disease and this makes prevention of the disease crucial to its control. Therefore, a lack of understanding of the disease and how to prevent it will place the health care workers at risk of infection, and if infected can transmit the infection to members of their family and the community at large. In addition, there may be a delay in prompt diagnosis and subsequent management or referral of such patients suspected of having the virus if health care workers lack adequate information and a high index of suspicion for the disease.

At the onset of the pandemic in Nigeria, the Ogun State Government in collaboration with partners such as World Health Organization (WHO) and Nigeria Centre for Disease Control (NCDC) organized training for health care workers to strengthen preventive strategies and raise awareness of the disease. This study is important in a setting like the COVID-19 pandemic to understand health care workers' knowledge especially with rapid turnover of information within a context of ongoing misinformation about the disease. Hence this study aimed to assess the knowledge, perception, and preventive practices of COVID19 among primary health care workers in Ogun State.

\section{Methods}

Study area and study period

This study was carried out in Ogun East Senatorial District in Ogun State, Nigeria between January and April 2021. Ogun State is located in southwest Nigeria. It has a total land area of $16,409.26 \mathrm{sq} . \mathrm{km}$. Its boundaries are Oyo and Osun States in the North, Ondo State in the East, Lagos in the South, and Republic of Benin in the West. The Capital of Ogun State is Abeokuta which lies about $100 \mathrm{~km}$ north of Lagos, Nigeria's business capital. The projected population of the State is $3,728,098$ disaggregated into $1,847,243$ males and 
$1,880,855$ females according to the national census carried out in 2006. The main ethnic group in the state is the Yoruba ethnic group of Nigeria.

The state has 20 local government Areas and is divided into three (3) senatorial districts: Ogun East, Ogun Central, and Ogun West. The state has two (2) federal tertiary hospitals, one (1) state tertiary hospital, thirty-nine (39) public secondary health facilities, four hundred and fifty (450) primary health facilities, one (1) private tertiary facility, and nine hundred and four (904) private health facilities. Ogun East senatorial district comprises of 9 LGAs; Sagamu, Ikenne, Remo North, Odogbolu, ljebu North, ljebu North East, ljebu Ode, ljebu East, and Ogun Waterside

\section{Study design}

This study was a descriptive cross-sectional study.

\section{Study population}

Health care workers in primary health centers in Ogun East Senatorial District.

\section{Sample size and sampling method}

A total of 339 respondents were recruited for the study. Participants were selected using a two-stage sampling method. The first step was the selection of five Local Government Areas out of 9 using a simple random sampling method. Next, four Primary Health Care facilities were selected from within each selected Local Government by simple random sampling. Every primary health care staff available at the time of the study were then recruited.

\section{Data collection}

Data were collected using a self-administered, semi-structured questionnaire made up of three sections. The first section contained questions on sociodemographic characteristics of the participants while the second, third, and fourth sections consisted of questions on knowledge, perception, and preventive practices of COVID19 respectively. The questionnaires were pretested among health workers in another senatorial district within Ogun state before administration and adjustments were made where needed.

\section{Measurements}

Knowledge of COVID-19 was measured using 13 items. Each correct item was coded as ' 1 ' while an incorrect answer was coded as ' 0 '. The total score was calculated (range 0-13) and categorized. Respondents who had scores $\leq$ $75 \%$ were considered as having poor knowledge. while those with scores above $75 \%$ were considered as having good knowledge.

Perception of COVID-19 was measured using 13 items. These were answered using a 5-point Likert scale: strongly agree, agree, not sure, disagree, strongly disagree. These were scored from five (strongly agree) to one strongly disagree for positively worded questions. Negatively worded questions were recoded to ensure adequate scoring. Higher values indicated good perception. The cumulative perception score was then computed (range 13-65). Respondents who scored $\leq$ mean score were categorized as having poor perception while those who scored above the mean score were categorized as having good perception. The practice of COVID-19 prevention methods was measured using 12 items with 'Yes', 'No', or 'Sometimes' as answers. A score of '2' was given for a 'Yes', ' 0 ' for 'No' and '1' for 'Sometimes'. The total practice score was computed (range 0-24). Respondents with scores of $<75 \%$ were categorized as poor practice while those with scores $\geq 75 \%$ were categorized as good practice.

\section{Data Analysis}

Data collected was cleaned and analyzed using IBM SPSS Statistics for Windows, Version 20. Results were presented as tables and charts. Descriptive analysis was done for variables as necessary. Chi-square was used for the bivariate analysis of variables with the level of significance set at $p<0.05$.

\section{Results}

Table 1: Sociodemographic characteristics

\begin{tabular}{|c|c|c|}
\hline Variable & Frequency & Percentage \\
\hline \multicolumn{3}{|l|}{ Age group } \\
\hline$<45$ & 196 & 57.8 \\
\hline$\geq 45$ & 143 & 42.2 \\
\hline \multicolumn{3}{|l|}{ Mean $=42.30 \pm 8.73$} \\
\hline \multicolumn{3}{|l|}{ Sex } \\
\hline Male & 43 & 12.7 \\
\hline Female & 296 & 87.3 \\
\hline Marital status & & \\
\hline
\end{tabular}




\begin{tabular}{lcc}
\hline Single & 43 & 12.7 \\
Married & 277 & 81.7 \\
Divorced/separated/widowed & 19 & 5.6 \\
Family type (n=330) & & \\
Monogamous & 249 & 75.5 \\
Polygamous & 81 & 24.5 \\
Educational Level & & \\
Primary & 8 & 2.4 \\
Secondary & 25 & 7.4 \\
Tertiary & 306 & 90.3 \\
Tribe & & \\
Yoruba & 322 & 95.0 \\
lgbo & 9 & 2.7 \\
Hausa & 6 & 1.8 \\
Others & 2 & 0.5 \\
Religion & & \\
Christianity & 273 & 80.5 \\
Islam & 61 & 18.0 \\
Others & 5 & 1.5 \\
Occupation & & \\
Doctor & 6 & 1.8 \\
Nurse & 30 & 8.8 \\
Community Health Extension Worker & 143 & 42.2 \\
Environmental Health Officer & 42 & 12.4 \\
Others & 118 & 34.8 \\
Service years & & \\
S10 years & 98 & 28.9 \\
11-20 years & 150 & 44.2 \\
>20 years & 91 & 26.8 \\
Mean service years = 15.69 $\pm \mathbf{8 . 3 2}$ & & \\
Attended Covid training & & \\
Yes & 241 & 71.1 \\
No & 98 & 28.9 \\
\hline
\end{tabular}

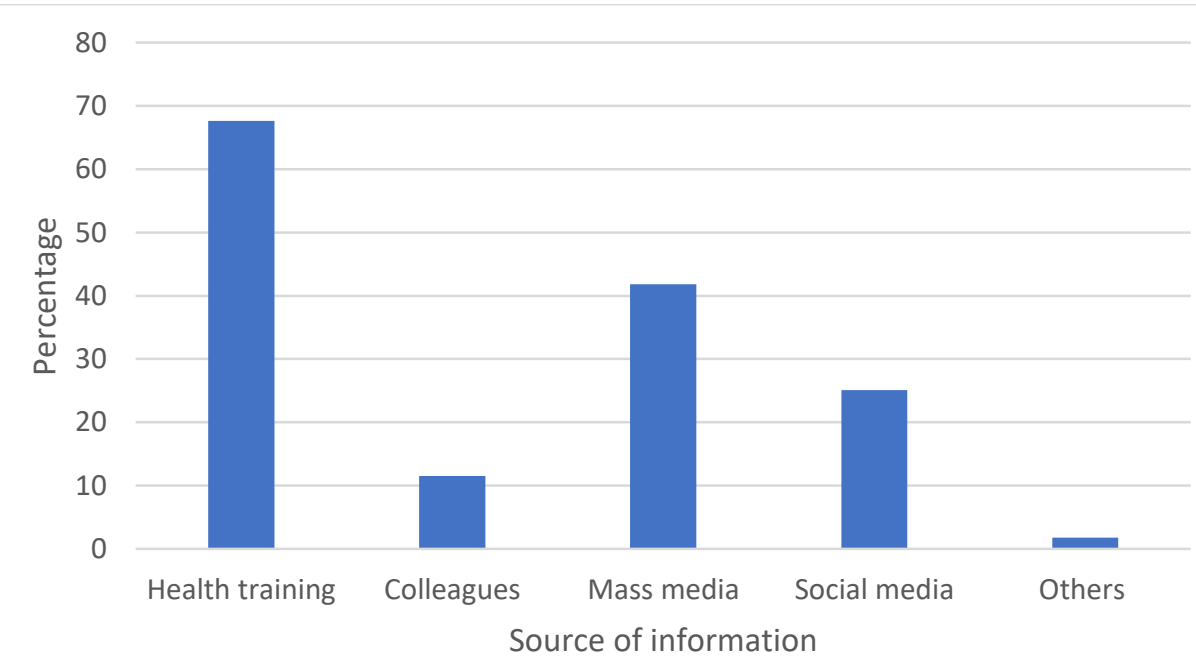

Figure 1: Source of information on COVID-19

Table 1 shows the sociodemographic characteristics of the respondents. Over half of them were aged $\leq 42$ years with the majority of them being females $(87.3 \%)$. About threequarters of the respondents were married and $73.5 \%$ were from a monogamous family. Most participants had tertiary-level education with a large number being Christians. More than half of them $(71.1 \%)$ had attended a COVID-19 training with $70.1 \%$ having attended training that lasted for less than one week. 
The majority of the respondents got their information from health training (67.6\%) followed by mass media $(41.8 \% \%)$, social media $(25.1 \%)$, and colleagues $(11.5 \%)$.

Table 2a: Knowledge of COVID-19 among primary health care workers

\begin{tabular}{|c|c|c|}
\hline Variables $\mathbf{N}=339$ & Frequency & Percentage \\
\hline What is the cause of COVID-19? & & \\
\hline Bacteria & 17 & 5.0 \\
\hline Fungi & 1 & 0.3 \\
\hline Virus & 309 & 91.2 \\
\hline $\begin{array}{l}\text { I don't know } \\
\text { *How is COVID-19 transmitted? }\end{array}$ & 12 & 3.5 \\
\hline Air droplets (from patient sneezing or coughing) & 272 & 80.2 \\
\hline Mosquitoes/flies & 2 & 0.6 \\
\hline Contact with contaminated surfaces & 163 & 48.1 \\
\hline $\begin{array}{l}\text { Close contact with people who have the virus } \\
\text { How long does it take from contacting the disease to the showing } \\
\text { of symptoms (Incubation period)? }\end{array}$ & 214 & 63.1 \\
\hline Less than 7 days & 53 & 15.6 \\
\hline $1-14$ days & 206 & 60.8 \\
\hline 2-21 days & 13 & 3.8 \\
\hline I don't know & 67 & 19.8 \\
\hline *Which is a symptom of COVID-19? & & \\
\hline Fever & 330 & 97.3 \\
\hline Runny nose & 282 & 83.2 \\
\hline Dry cough & 306 & 90.3 \\
\hline Breathing difficulty & 324 & 95.6 \\
\hline Muscle pain & 161 & 47.5 \\
\hline Fatigue & 162 & 47.8 \\
\hline Bleeding & 41 & 12.1 \\
\hline Who can get infected with COVID-19? & & \\
\hline Old people only & 5 & 1.5 \\
\hline Young adults only & 4 & 1.2 \\
\hline $\begin{array}{l}\text { Anyone can be infected } \\
\text { Is it possible for a COVID-19 positive person to show no } \\
\text { symptoms? }\end{array}$ & 330 & 97.3 \\
\hline Yes & 246 & 72.6 \\
\hline No & 81 & 23.9 \\
\hline I don't know & 12 & 3.5 \\
\hline
\end{tabular}

*Multiple responses allowed

Table 2b: Knowledge of COVID-19 among primary health care workers

\begin{tabular}{lcc}
\hline \multicolumn{1}{c}{ Variable N = 339 } & Frequency & Percentage \\
\hline *What can kill the organism that causes COVID-19? & 217 & 64.0 \\
Diluted chlorine & 314 & 92.6 \\
Alcohol based sanitizers & 287 & 84.7 \\
Soap/detergents & 2 & 0.6 \\
Water alone & 4 & 1.2 \\
I don't know & 339 & 100 \\
Is handwashing important in the prevention of COVID-19? & \\
Yes & & 27.4 \\
If Yes, how long should you wash your hands to kill the organism & 61.9 \\
causing COVID-19? & 93 & 10.6 \\
Less than 20 secs & 210 & \\
20secs to 60 secs & 36 & 73.2 \\
I don't know & & 25.7 \\
Does COVID-19 have a cure? & 248 \\
Yes & 87 & 1.2 \\
No & 4 & \\
\hline
\end{tabular}




\begin{tabular}{lcc}
\hline *If Yes, what is the cure? & & \\
Chloroquine & 95 & 28.0 \\
Antibiotics & 92 & 27.1 \\
Drinking hot water & 94 & 27.7 \\
Drinking hot ginger/turmeric & 70 & 20.6 \\
Drinking alcohol & 8 & 2.4 \\
Other (specify & 34 & 10.0 \\
Is there a vaccine for CoVID-19? & 162 & 47.8 \\
Yes & 76 & 22.4 \\
No & 101 & 29.8 \\
I don't know & &
\end{tabular}

Knowledge of COVID-19

Almost all (99.7\%) of the respondents had heard about COVID-19. Tables 2a and b show the knowledge of COVID-19 among respondents. A total of $309(91.2 \%)$ correctly identified the cause of the disease with $60.8 \%$ identifying the incubation period for the disease. About three quarters correctly identified the mode of transmission as air droplets while $63.1 \%$ identified close contact with people who have the virus as a mode of transmission. Only $48.1 \%$ were aware that COVID-19 could be transmitted via contact with contaminated surfaces. For overall knowledge, the mean score was $9.35 \pm 1.32$ with the least score being 4 and the maximum score 12 . Out of 339 respondents, $49.3 \%$ had poor knowledge and $50.7 \%$ had good knowledge concerning COVID-19.

Table 3: Perception of COVID-19

\begin{tabular}{|c|c|c|c|c|c|}
\hline Variable & $\begin{array}{l}\text { Strongly } \\
\text { agree } \\
\text { n (\%) }\end{array}$ & $\begin{array}{l}\text { Agree } \\
\text { n (\%) }\end{array}$ & $\begin{array}{l}\text { Not sure } \\
\text { n (\%) }\end{array}$ & $\begin{array}{c}\text { Disagree } \\
\mathrm{n}(\%)\end{array}$ & $\begin{array}{l}\text { Strongly } \\
\text { disagree } \\
\mathrm{n}(\%)\end{array}$ \\
\hline COVID-19 is a deadly disease & $225(66.4)$ & $92(27.1)$ & $9(2.7)$ & $5(1.5)$ & $8(2.4)$ \\
\hline I am at risk of contracting COVID-19 & $107(31.6)$ & $130(38.3)$ & $28(8.3)$ & $52(15.3)$ & $22(6.5)$ \\
\hline COVID-19 is highly infectious & $197(58.1)$ & $120(35.4)$ & $20(5.9)$ & $2(0.6)$ & \\
\hline $\begin{array}{l}\text { COVID-19 infection is just being } \\
\text { exaggerated }\end{array}$ & $25(7.4)$ & $22(6.5)$ & $30(8.8)$ & $138(40.7)$ & $124(36.6)$ \\
\hline I don't believe COVID-19 infection exists & $11(3.2)$ & $17(5.0)$ & $12(3.5)$ & $132(38.9)$ & $167(49.3)$ \\
\hline $\begin{array}{l}\text { COVID- } 19 \text { infection is an intention for } \\
\text { corruption by the government }\end{array}$ & $17(5.0)$ & $21(6.2)$ & 37 (10.9) & $172(50.7)$ & $92(27.1)$ \\
\hline $\begin{array}{l}\text { Even in areas experiencing outbreaks, } \\
\text { meat products can be safely consumed if } \\
\text { these items are cooked thoroughly and } \\
\text { properly handled during food preparation }\end{array}$ & $98(28.9)$ & $139(41.0)$ & $57(16.8)$ & $35(10.3)$ & $10(2.9)$ \\
\hline $\begin{array}{l}\text { If anyone has a fever, cough, and difficulty } \\
\text { in breathing, COVID-19 should be } \\
\text { suspected }\end{array}$ & $229(67.6)$ & $92(27.1)$ & & $7(2.1)$ & $11(3.2)$ \\
\hline $\begin{array}{l}\text { As per WHO guidelines for COVID-19, you } \\
\text { only need to wash your hands when they } \\
\text { are visibly dirty }\end{array}$ & $56(16.5)$ & $40(11.8)$ & $10(2.9)$ & 97 (28.6) & $136(40.1)$ \\
\hline $\begin{array}{l}\text { The use of facemask is important in } \\
\text { preventing COVID-19 infection }\end{array}$ & $236(69.6)$ & $93(27.4)$ & $4(1.2)$ & $4(1.2)$ & $2(0.6)$ \\
\hline $\begin{array}{l}\text { Social distancing is important in preventing } \\
\text { COVID-19 infection }\end{array}$ & $240(70.8)$ & $91(26.8)$ & $6(1.8)$ & & $2(0.6)$ \\
\hline $\begin{array}{l}\text { Strict infection control policy is important in } \\
\text { preventing COVID-19 in }\end{array}$ & $190(56.0)$ & 108 (31.9) & $24(7.1)$ & $12(3.5)$ & $5(1.5)$ \\
\hline $\begin{array}{l}\text { Vaccines are not needed in the control of } \\
\text { COVID-19 in Nigeria }\end{array}$ & $23(6.8)$ & 35 (10.3) & $52(15.3)$ & $120(35.4)$ & 109 (32.2) \\
\hline
\end{tabular}

Perception of COVID-19

Table 3 shows respondents' perception of COVID-19. Over half of the respondents strongly agreed that COVID-19 is a deadly disease while only $31.6 \%$ and $38.3 \%$ strongly agreed or agreed that they were at risk of contracting the disease. Less than $10 \%$ of the respondents strongly agreed that COVID-19 is 
just being exaggerated and 5\% strongly believed that COVID-19 is an intention for corruption by the government. Overall, the mean perception score was 32.64 with minimum and maximum scores of 17 and 47 respectively. A total of $194 \quad(57.2 \%)$ respondents had a poor perception of COVID19 while the remaining respondents had a good perception of COVID-19.

Table 4: Practice of COVID-19 prevention measures

\begin{tabular}{|c|c|c|c|}
\hline Variable & $\begin{array}{c}\text { Always } \\
\text { n (\%) }\end{array}$ & $\begin{array}{c}\text { Sometimes } \\
n(\%)\end{array}$ & $\begin{array}{c}\text { Not at all } \\
\mathrm{n}(\%)\end{array}$ \\
\hline Educate your patients about COVID-19 & $316(93.2)$ & $21(6.2)$ & $2(0.6)$ \\
\hline Use facemasks in crowds & $326(96.2)$ & $13(3.8)$ & $0(0.0)$ \\
\hline $\begin{array}{l}\text { Cover your nose and mouth with a tissue during } \\
\text { sneezing or coughing }\end{array}$ & $297(87.6)$ & $16(4.7)$ & $26(7.7)$ \\
\hline $\begin{array}{l}\text { Avoid touching your eyes, nose, or mouth as far as you } \\
\text { can }\end{array}$ & $301(88.8)$ & 33 (9.7) & $5(1.5)$ \\
\hline Use soap or hand sanitizer to wash your hands regularly & 315 (92.9) & $21(6.2)$ & $3(0.9)$ \\
\hline Throw used tissue in the trash & $288(85)$ & $26(7.7)$ & $25(7.4)$ \\
\hline Practice social distancing as recommended & $308(90.9)$ & $29(8.6)$ & $2(0.6)$ \\
\hline $\begin{array}{l}\text { Strictly follow national/state protocol for triage and } \\
\text { isolation of suspected COVID-19 cases }\end{array}$ & $299(88.2)$ & $30(8.8)$ & $10(2.9)$ \\
\hline $\begin{array}{l}\text { Disinfect tables and working rooms before and after } \\
\text { work }\end{array}$ & $280(82.6)$ & $42(12.4)$ & $17(5.0)$ \\
\hline $\begin{array}{l}\text { Ensure that patients are adequately spaced while giving } \\
\text { health education or waiting to be attended to }\end{array}$ & $312(96.2)$ & $15(4.4)$ & $8(2.4)$ \\
\hline $\begin{array}{l}\text { Have a holding area for isolation of suspected COVID- } \\
19 \text { cases }\end{array}$ & $260(76.7)$ & $20(5.9)$ & $59(17.4)$ \\
\hline $\begin{array}{l}\text { Ensure that all patients wear facemask before entering } \\
\text { your facility or being attended to by health workers }\end{array}$ & $318(93.8)$ & $18(5.3)$ & $3(0.9)$ \\
\hline $\begin{array}{l}\text { Have IEC materials for educating patients on COVID-19 } \\
\text { in your facility }\end{array}$ & $250(73.7)$ & $21(6.2)$ & $68(20.1)$ \\
\hline $\begin{array}{l}\text { Have a copy of the national/state protocols or guidelines } \\
\text { for triage and isolation of suspected COVID-19 cases in } \\
\text { your facility }\end{array}$ & $229(67.6)$ & $13(3.8)$ & $97(28.6)$ \\
\hline $\begin{array}{l}\text { Are you willing to take the COVID-19 vaccine when } \\
\text { available? }\end{array}$ & $200(59.0)$ & $7(2.1)$ & $132(38.9)$ \\
\hline
\end{tabular}

*IEC: Information, Education, and Communication

The practice of COVID-19 preventive measures Table 4 shows the practice of COVID-19 preventive measures. The majority of the respondents $(93.2 \%)$ educate their patients about COVID-19 and $96.2 \%$ use facemasks in crowds. Only $76.7 \%$ have a holding area for the isolation of suspected COVID-19 cases. Just a little over half $(59.0 \%$ were willing to take the COVID-19 vaccine when available. Overall, the mean practice score was $22.22 \pm 2.79$ with minimum and maximum scores of 12 and 24 respectively. The majority $(92.9 \%)$ had good practice while $7.1 \%$ had poor practice.

In addition, almost all (98.2\%) of the respondents had the necessary personal protective equipment. The most readily available personal protective wear was the face mask $(96.5 \%)$. Personal protective equipment was provided by $67.8 \%$ of the respondents themselves.

Table 5: Factors affecting knowledge of COVID-19

\begin{tabular}{lcccc}
\hline Variable (N=339) & Poor $\mathbf{n}(\%)$ & Good $\mathbf{n}(\%)$ & $\mathbf{X 2}^{2}$ & p value \\
\hline Age group & $104(62.3)$ & $92(53.5)$ & & \\
$<45$ & $63(37.7)$ & $80(46.5)$ & 2.683 & 0.101 \\
$\geq 45$ & $20(12.0)$ & $23(13.4)$ & & \\
Sex & $147(88.0)$ & $149(86.6)$ & 0.149 & 0.699 \\
Male & & & & \\
Female & $22(13.2)$ & $21(12.2)$ & & \\
Marital status & & &
\end{tabular}




\begin{tabular}{|c|c|c|c|c|}
\hline Married & $135(80.8)$ & $142(82.6)$ & & \\
\hline $\begin{array}{l}\text { Separated/Divorced/widowed } \\
\text { Family type }(\mathbf{n}=\mathbf{3 3 0})\end{array}$ & $10(6.0)$ & $9(5.2)$ & 0.179 & 0.914 \\
\hline Monogamous & 119(72.3) & 130(78.3) & & \\
\hline $\begin{array}{l}\text { Polygamous } \\
\text { Educational Level }\end{array}$ & $45(27.7)$ & $36(21.7)$ & 1.474 & 0.225 \\
\hline Primary/secondary & $20(12.0)$ & $13(7.6)$ & & \\
\hline $\begin{array}{l}\text { Tertiary } \\
\text { Tribe }\end{array}$ & $147(88.0)$ & $159(92.4)$ & 1.882 & 0.170 \\
\hline Yoruba & $157(94.0)$ & 165(95.9) & & \\
\hline Others & $10(6.0)$ & $7(4.1)$ & 0.655 & 0.418 \\
\hline Religion & & & & \\
\hline Christianity & $131(78.4)$ & 142(82.6) & & \\
\hline Others & $36(21.6)$ & $30(17.4)$ & 0.915 & 0.339 \\
\hline Occupation & & & & \\
\hline Doctor/Nurse & $13(7.8)$ & 23(13.4) & & \\
\hline Community Health Extension Workers & $76(45.5$ & $67(39.0)$ & & \\
\hline Environmental Health Officers & 24(14.4) & 18(10.5) & & \\
\hline Others & $54(32.3)$ & $64(37.2)$ & 4.976 & 0.174 \\
\hline Service years & & & & \\
\hline$\leq 10$ years & $50(29.9)$ & $48(27.9)$ & & \\
\hline $11-20$ years & 83(49.7) & $67(39.0)$ & & \\
\hline $\begin{array}{l}>20 \text { years } \\
\text { Attended Covid training }\end{array}$ & $34(20.4)$ & $57(33.1)$ & 7.489 & $0.024^{*}$ \\
\hline Yes & 113(67.7) & $128(74.4)$ & & \\
\hline No & $54(32.3)$ & $44(25.6)$ & 1.881 & 0.170 \\
\hline Duration of covid training $=\mathbf{2 4 1}$ & & & & \\
\hline $\begin{array}{l}<1 \text { week } \\
\geq 1 \text { week }\end{array}$ & $95(84.1)$ & $113(88.3)$ & 000 & 0313 \\
\hline$\geq 1$ week & 18(15.9) & 15(11.7) & 0.900 & 0.343 \\
\hline
\end{tabular}

Length of years in service was significantly associated with knowledge of COVID-19 $\left(X^{2}=10.404 ; p\right.$ value $\left.=0.0034\right)$ with those who have been in service between 11-20 years more likely to have good knowledge.

\section{Discussion}

Health care workers play a critical role in the prevention and control of epidemic diseases including COVID-19. Their role as frontline workers responding to the epidemic and source of health information in the community where they reside make them a vital stakeholder in the control of the current COVID-19 pandemic, more especially at the primary health care level which is the entry point into the country's health care system.

Only about half of the respondents in this study had good knowledge of COVID-19. This is however higher than $9.3 \%$ reported in a study of community health workers in a rural area in Cross-River State, Nigeria (11). The higher level of knowledge obtained in this current study could be because the respondents in the study were made up of health care workers from both urban and rural areas who had been exposed to training on COVID-19 both by government and other non-governmental organizations as a result of the rapid response to the emerging pandemic in the state.

The finding from this study is, however, lower than $88.59 \%, 90 \%$ and $83.7 \%(12,13,14)$ reported in Anambra State, Bayelsa State, and Kano State, Nigeria respectively. These studies could be biased because the respondents were selected from web-based participants who were likely to have access to other health information on the web as a result of their activity. Similarly, studies conducted among health workers in Nepal and China reported that $63.2 \%$ and $88.4 \%$ had good knowledge of COVID-19 (15, $16)$. This could be attributed to the fact that some of these studies were carried out in tertiary facilities with better infrastructure, access to information, training, and continuing medical education which may not be readily available at the primary health care level of the health care system. In addition, the categories of healthcare workers interviewed in these other studies were more nurses and physicians compared to community health extension workers in this study.

This current study found an association between the length of years spent in service by the healthcare worker and the level of knowledge on COVID-19 $(p=0.024)$, with those 
who had been in service for more than 10 years more likely to have a good level of knowledge compared to those who had spent fewer years in service. This could be because in practice, people in higher cadres are more likely to be sent for training on emerging issues and this perhaps could have resulted in them developing networks whereby, they have access to current information relevant to health compared to people in lower cadres.

A study done in Kano State, identified marital status, professional categorization, and type of health facility as factors associated with good knowledge among respondents. Respondents who were divorced had $90 \%$ less knowledge compared to those who were single and doctors were the most knowledgeable. The study also reported that respondents working in the tertiary facilities were most knowledgeable about COVID-19. However, the study did not find any association between age, gender, highest qualification, and knowledge of COVID19 (12). Similarly, a study carried out in Bayelsa state reported an association between knowledge scores and category of health workers with nurses and doctors having a significantly higher knowledge score compared to other health workers. It also identified that respondents who were younger than 30 years old had higher mean scores compared to those who were older and this was statistically significant (13). In consonance with the current study, both studies did not find any association between age, gender, highest qualification, and knowledge of COVID-19.

Good perception of the risk of COVID-19 was recorded among $42.8 \%$ of the respondents. It is, however, lower than $78.9 \%$ reported in Kano State (12). About $32 \%$ and $38 \%$ of the respondents strongly agreed and agreed respectively that they were at risk of contracting COVID-19. This is similar to what was reported in Addis Ababa, Ethiopia where $43 \%$ and $30 \%$ strongly agreed and agreed that they were at risk of contracting COVID-19 (14). The low level of good risk perception reported in this current study is quite worrisome considering that the health workers are expected to be the agents of change in the communities where they work.

The majority $(92.9 \%)$ of the respondents in this study had good preventive practices towards the virus. This is higher than $77.6 \%$ reported in Kano State (12) and $81.39 \%$ reported in Anambra State (15). The finding is similar to studies conducted in Addis Ababa and China $(14,16)$ where the majority of the respondents had high levels of preventive practice towards COVID-19. The high level of good preventive practice in this current study could be attributed to the fact that more than half $(68 \%)$ of the respondents thought that they were at risk of contracting COVID-19 and this perhaps made them willing to protect themselves from being infected with the virus by providing personal protective equipment for themselves even when their employers did not provide such. This study, however, did not find any association between preventive practices and sociodemographic risk factors though some studies have reported an association between knowledge of COVID-19 and good preventive practices among healthcare workers $(12,13$, 14).

\section{Conclusion}

In conclusion, only about half of the respondents had good knowledge of COVID-19 with a poor perception rate. The majority had good practices to prevent themselves from contracting the disease. Efforts should be made to further improve the knowledge of primary health care workers as they play a vital role in the delivery of health care services, especially in this period of the ongoing COVID-19 pandemic. The government needs to provide adequate personal protective equipment for health care workers to discharge their responsibility without the fear of being infected or infecting members of their families.

\section{List of abbreviations}

CHEW: Community Health Extension Workers LGA: Local Government Area

NCDC: Nigeria Centre for Disease Control

WHO: World Health Organization

\section{Declarations}

Ethics approval and consent to participate

Ethical approval was obtained from the Ministry of Health Ogun State (HPRS/381/354 dated 28/01/2021) before the commencement of the research. In addition, permission was sought from the heads of the facilities used for the study. Informed consent was obtained from each of the participants before administering the questionnaires. The questionnaire was translated to Yoruba which is the predominant language in Ogun East Senatorial district for better understanding and translated back to English to ensure that the original meaning was retained. The information obtained had no identifier that could link the information back to the participants.

\section{Consent for publication}

The authors hereby give consent for the publication of our work under the creative 
commons CC Attribution-Non-commercial 4.0 license.

\section{Competing Interests}

There is no competing interest.

Funding

None.

\section{Authors' Contributions}

Conceptualization and study design: DO, BJ, GA

Data collection: BJ, GA, OA, AO

Data analysis: DO, BJ, OA, AO

Study supervision: DO, BJ, GA

Manuscript writing: DO, BJ, GA, OA, AO

Revision of manuscript for intellectual content: DO, BJ, GA

\section{Acknowledgments}

We express our thanks to all individuals who participated in this study.

\section{References}

1. Lai CC, Shih TP, Ko WC, Tang HJ, Hsueh PR. Severe acute respiratory syndrome coronavirus 2 (SARS-CoV-2) and coronavirus disease-2019 (COVID-19): The epidemic and the challenges. International journal of antimicrobial agents. 2020 Mar 1;55(3):105924.

https://doi.org/10.1016/j.ijantimicag.2020.10 5924

2. Eurosurveillance Editorial Team. Note from the editors: World Health Organization declares novel coronavirus (2019-nCoV) sixth public health emergency of international concern. Eurosurveillance. 2020 Feb 6;25(5):200131e. https://doi.org/10.2807/15607917.es.2020.25.5.200131e

3. World Health Organization (WHO). Novel Coronavirus ( 2019-nCoV ) Situation Report - 121 January 2020. WHO Bull. 2020:1-7.

4. Nigeria Center for Disease Control. NCDC Covid update [Internet]. 2021. Available from: $\quad$ https://covid19.ncdc.gov.ng/ Accessed 28.6.21

5. Gralinski LE, Menachery VD. Return of the Coronavirus: 2019-nCoV. Viruses. 2020 Feb;12(2):135. https://doi.org/10.3390/v12020135

6. World Health Organization. Modes of transmission of the virus causing COVID-19: implications for IPC precaution recommendations: scientific brief, 29 March 2020. World Health Organization; 2020.

7. Abdelhafiz AS, Mohammed Z, Ibrahim ME, Ziady HH, Alorabi M, Ayyad M, Sultan EA.
Knowledge, perceptions, and attitude of Egyptians towards the novel coronavirus disease (COVID-19). Journal of community health. 2020 Oct;45(5):881-90. https://doi.org/10.1007/s10900-020-00827$\underline{7}$

8. World Health Organization. Infection prevention and control during health care when novel coronavirus (nCoV) infection is suspected Interim guidance, 19 March 2020.

9. World Health Organization. Coronavirus disease (COVID-19) advice for the public: Myth busters. 2020. Viewed in June 2020 Apr;30.

10. Habib MA, Dayyab FM, lliyasu G, Habib AG. Knowledge, attitude and practice survey of COVID-19 pandemic in Northern Nigeria. PLoS One. 2021;16:1-12. https://doi.org/10.1371/journal.pone.024517 $\underline{6}$

11. Omoronyia O, Ekpenyong $\mathrm{N}$, Ukweh I, Mpama E. Knowledge and practice of COVID-19 prevention among community health workers in rural cross river state, Nigeria: Implications for disease control in Africa. Pan Afr Med J. 2020;37(50):1-12. https://doi.org/10.11604/pamj.2020.37.50.2 4307

12. Tsiga-Ahmed $\mathrm{FI}$, Amole TG, Musa BM, Nalado AM, Agoyi OB, Galadanci HS, et al. COVID 19: Evaluating the Knowledge, Attitude and Preventive Practices of Healthcare Workers in Northern Nigeria. Int J MCH AIDS. 2021;10(1):88-97.

13. Egbi OG, Duru C, Kasia B. Knowledge, attitude and practice towards COVID-19 among workers of a tertiary hospital in Bayelsa State, Nigeria. Pan Afr Med J. 2020;37(Supp

1):24. https://doi.org/10.11604/pami.supp.2020.37 .1 .26259

14. Deressa W, Worku A, Abebe W, Gizaw M, Amogne W. Risk perceptions and preventive practices of COVID-19 among healthcare professionals in public hospitals in Addis Ababa, Ethiopia. PloS one. 2021 Jun 25;16(6):e0242471. https://doi.org/10.1371/journal.pone.024247 1

15. Pauline Mbachu CN, Azubuike CMC, Mbachu II, Ndukwu Cl, Ezeuko AYA, Udigwe IB, et al. COVID-19 infection: Knowledge, attitude, practices, and impact among healthcare workers in a SouthEastern Nigerian state. J Infect Dev Ctries. 2020;14(9):943-52. https://doi.org/10.3855/iidc. 13248

16. Lai X, Wang X, Yang Q, Xu X, Tang Y, Liu 
Daniel et. al. BUMJ 2021 4(2):140-150

$\mathrm{C}$, et al. Will healthcare workers improve infection prevention and control behaviors as COVID-19 risk emerges and increases, in China? Antimicrob Resist Infect Control. 2020;9(1):1-9.

https://doi.org/10.1186/s13756-020-007461 